\title{
ON THE DEVELOPMENT OF THE EXTRA-OCULAR MUSCLES IN SOME MAMMALS
}

\author{
BY \\ Professor Otokar Lešer, M.D. \\ Czechoslovak Ophthalmological Clinic, Prague \\ From the Czechoslovak Institute for Normal ANatomy \\ Director, Prof. Janašik
}

THE results of my investigations into the development of the bulbar musculature in man (published in my earlier work) induced me to extend my study also to a number of mammals in respect of which the rich collections of the Czechoslovak Institute for Normal Anatomy in Prague were at my disposal. I was able to make use of a complete series exhausting all the developmental stages of the Spermophilus citillus and Sus domesticus; in addition to which I always compared the results of my studies with observations made on the Vespertilio murinus, Canis, and Cuniculus.

As generally known, in lower vertebrates the orbital musculature is derived from the walls of the so-called "head cavities" (Corning, ${ }^{(1)}, \operatorname{Rex}^{(6)}$, Matys ${ }^{(5)}$, etc.); in mammals, however, it is impossible positively to find such structures as might be homologized with the head cavities of the reptiles, birds, etc. In respect of mammals the development of these particular muscles has been studied only on the embryos of the Sus domesticus (Kheil(3), Reuter, Keibel); the stages, however, described by these authors are far too advanced.

For easier understanding I first give a brief account of the muscular development in an embryo $7.6 \mathrm{~mm}$. long, in which the rudiments of the musculature innervated by the n. oculomotorius and $n$. abducens are already defined to some extent. If in this embryo we trace the $n$. abducens at its issue from the hindbrain, we shall find that it issues as a number (6-7) of nerve fibres which approach one another, produce a delicate, still undefined bundle extending in a distal and rostral direction towards the spot in which the infundibulum forms on the midbrain, and then pass on to the lateral area in the proximity of the carotid artery. Opposite the infundibulum the hypophysis evaginates out of the pharynx. In the indicated spot, near the carotid, the nerve fibres become lost in a condensation of mesoblastic cells. This condensation is sufficiently well-defined and passes as a spindle-shaped structure to the rostrum and to the lateral area towards where the peduncle of the optic vesicle is situated. The process for the development of the upper jaw is still very slight, 
in consequence of which this part of the first muscular development seems to be situated in close proximity to the palate. At this stage the $n$. oculomotorius is much more vigorous than the n. abducens, extends ventrally, closely adjoins the jugular vein, and lodges upon the aforementioned cellular condensation deposited around the $\mathrm{n}$. abducens. On section the cellular condensation forms an oval group of cells, rather large and distinctly circumscribed, in which the laterally deposited group obviously pertains to the $\mathrm{n}$. abducens, the medial group pertaining to the $\mathrm{n}$. oculomotorius. This fusiform structure, equally dependent on the two nerves, continues its course towards the peduncle of the optic vesicle and nearly to the vesicle itseif. The $n$. oculomotorius enters the cellular group much nearer the eye than does the $n$. abducens. The cellular group treated of

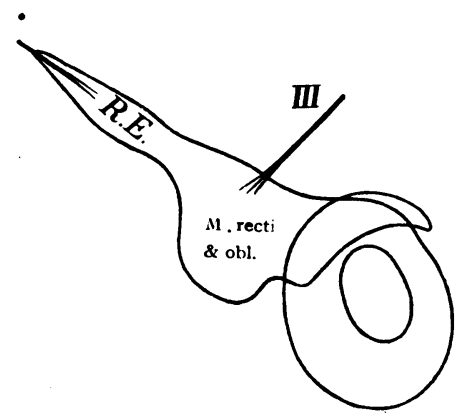

Fig. 1.

Embryo $7.6 \mathrm{~mm}$. of the Spermophilus citillus

above extends in two to three offshoots into the other mesoblastic ceils near the eye, and, in consequence, its termination is not distinct.

After the discovery of this obvious commencement of the development of the ocular musculature, it was necessary to look for earlier stages. I set out to examine the stages of two or three mesoblastic somites in order that I might ascertain the origin of the cells producing musculature. It can be safely declared that in embyros of 1-3 mm. it is not at all possible to observe any such structures as might produce the muscle plate beyond the trigeminal ganglion by the otic vesicle and the adjacent ganglions-in the place of future generation of musculature. Only after the length of about $4 \mathrm{~mm}$. has been attained a somewhat denser group of mesoblastic cells can be discovered in the indicated locality, just in the angle inclosed by the carotid and jugular, as high up as where the notochord terminates in the pharyngeal portion of the embryo. 
Let us examine an embryo $3.7 \mathrm{~mm}$. long, just at the stage of invagination of the primary optic vesicle; the lens appears as a thickening of the epiblast tending towards the vesicle. At this developmental stage the $n$. oculomotorius is founded on a number of fibrils issuing from the brain and closely adjoins the jugular vein in its continued course. However, it does not yet reach the group of rather condensed cells between the carotid artery and the vein. It is not yet possible to trace the $\mathrm{n}$. abducens which is visible only at the very beginning of its issue from the brain. The rather condensed cells mentioned above, which are not distinctly differentiated from the surrounding mesoblastic cells, are deposited just where the first evagination for the hypophysis, and the evagination on the brain for the infundibulum are situated.

An embryo $4 \mathrm{~mm}$. long shows no particular changes as compared with the preceding stage. Neither the oculomotorius nor the abducens extend as far as their proper place. However, in the next stage-only a little older $(4.5 \mathrm{~mm}$.) - when the secondary optic vesicle is already formed (the anterior wall of the primary vesicle being already deeply invaginated towards the posterior wall) and the lens beginning to form a vesicle which is still open wide in the epiblast, we observe the $\mathrm{n}$. abducens at this stage passing into the aforesaid cellular condensation. The $\mathrm{n}$. oculomotorius extending close along the jugular vein does not yet reach the cells which are not yet distinctly defined in-their surroundings, and towards the eye becomes utterly lost amongst the other mesoblastic cells.

At the next stage of development, in an embryo of $5.5 \mathrm{~mm}$. the changes we find are more striking. The $n$. oculomotorius is much more vigorous, forming a solid nerve bundle, the n. abducens is by far the thinner. In section the plate of condensed cells is larger and forms a definite island of concentrically arranged cells, which extends along the carotid and is surrounded by a dense network of veins on the lateral side. According to the arrangement of cells at this stage it is already possible to observe that the cells deposited on the exterior for the most part belong to the $n$. abducens, while those situated medially belong to the n. oculomotorius. At the points, where in the section the optic vesicle is already reached, these cells cannot be detected.

An embryo of $6 \mathrm{~mm}$. does not appreciably differ from the preceding stage. The nerves cannot be traced amongst the cells with perfect distinction. As best seen in a model, the cellular condensation extends first as a cylindrical body surrounding the $\mathrm{n}$. abducens, and then is entered by the n. oculomotorius. In its further course it extends rostrally and towards the eye runs out into two processes. 
On comparison of the projections of the embryos just described the gradual growth of the oculomotor musculature and nerve connection will be distinctly perceived. In the first described embryo of $7.6 \mathrm{~mm}$. the beginning of the muscles innervated by the n. oculomotorius, and of the musc. rect. ext. innervated by the n. abducens, is already defined with perfect distinctness. The muscle plate for the n. oculomotorius begins to divide, still indistinctly, of course, into three plates, i.e., future muscles.

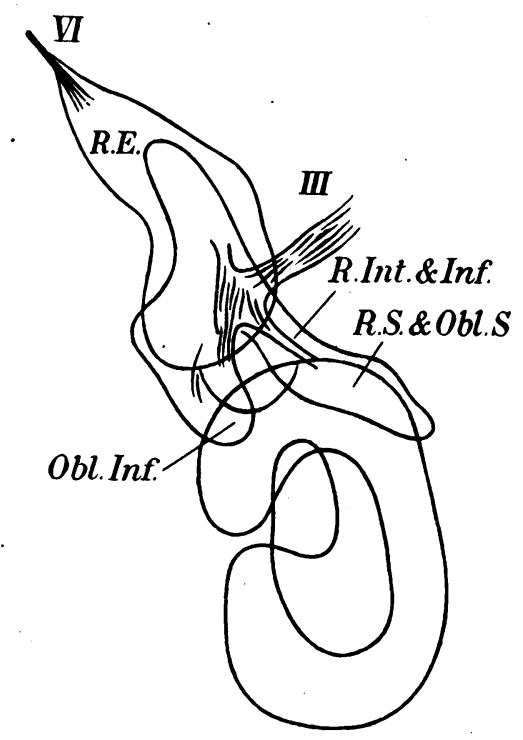

FIG. 2.

Embryo $8.4 \mathrm{~mm}$. of the Spermophilus citillus

This division is suggested by three digitiform outgrowths extending for different distances towards the optic cup. Each of these outgrowths is entered by a branch of the n. oculomotorius, as can be seen on the general projection. The ligamentous division of the individual plates-muscles-cannot be observed yet with any particular distinction despite the mesoblastic elements issuing out of the surrounding connective tissue and reaching amongst the condensed cells.

If we now pass to a stage of $8.4 \mathrm{~mm}$. the conditions we find do not essentially differ from those prevailing at the preceding stage. In point of growth, of course, the development of muscle plates has advanced so far that the digitiform processes of the plate, 
originally common for the oculomotor musculature, are now divided into three plates, each of which is entered by a branch of the common oculomotor 'trunk, which first spreads into a considerable area and then gives off the individual branches out of this expanded part. The plate of the $n$. abducens has grown both long and wide. At this stage of development it is already possible to distinguish the foundation of the four ocular muscles :

1. The musc, rect. ext. from the n. abducens and

2. The musc. rect. sup.

3. The musc. rect. inf. and

4. The musc. rect. inter. from the $n$. oculomotorius.

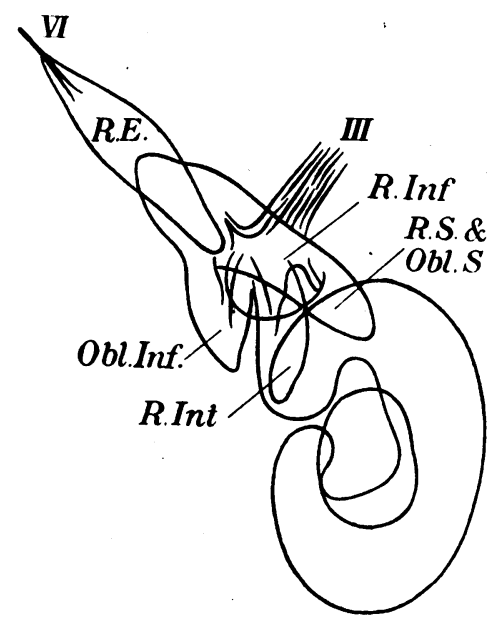

FIG. 3.

Embryo $9 \mathrm{~mm}$. of the

Spermophilus citillus.

These plates form, as it were, a basket on the posterior wall of the bulb. At this stage we must mention the peculiar conditions caused by the second branch of the $n$. trigeminus.

As stated above the foundation for the ocular musculature is situated in close connection with the ganglion of the fifth nerve, which, however, has nothing to do with the development of these muscles. However, at the stages of which I am treating we observe that the second branch of the fifth nerve also adjoins the very beginning of the muscle plates of the ocular musculature, and that around this branch there are also muscle cells which at some stages almost mingle with the cells of the eye muscles on the caudal pole. This, however, is a foundation for the masticatory musculature which develops in proximity to the eye muscles from 
the second branch of the fifth nerve. Such proximity and contact are contingent on the structure of the future orbit which in some mammals has its fissure open wide, and through this the masticatory muscles pass. Now I dare suggest that it may be due just to this circumstance that some authors regarded the development of the $\mathrm{m}$. rect. ext. as contingent on the fifth nerve.

At further larger stages we can especially observe the enlargement of the various processes, or, more exactly, the growing

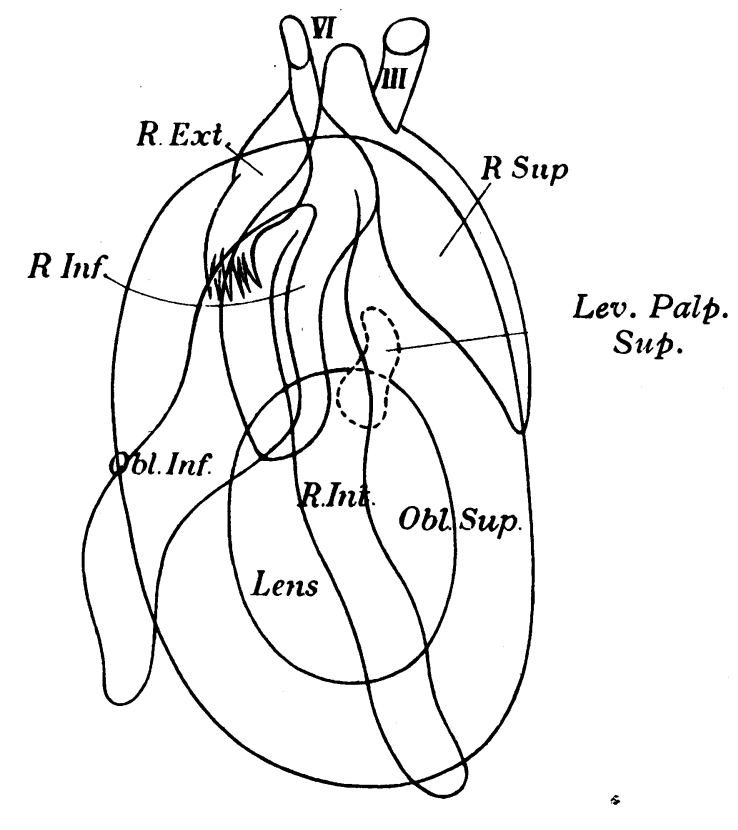

FIG. 4 .

Embryo $10 \mathrm{~mm}$. of the Spermophilus citillus.

of the various muscles towards the points of their attachment to the eye. The individual muscles are separated from one another by the intrusion of the mesoblastic cells, i.e., the connective tissue. As soon as the $n$. trochlearis has grown to its full extent and joined the plate it is easily possible to distinguish the developed $\mathrm{m}$. rect. ext., the cellular group for the musculature of the $\mathrm{n}$. oculomotorius, and the $\mathrm{m}$. obliqu. sup. which latter is derived from a portion of the oculomotor plate into which $\mathrm{n}$. trochlearis has intruded on its anterior part. The growth of the $\mathrm{m}$. rect. inf. is relatively very rapid. The plate for the 
m. rect. int. and the m. obl. inf. remains in common for a fairly long period of time, and it is only after the connective tissue has intruded that the two begin to divide. The longest remaining together in one plate are the $\mathrm{m}$. rect. sup., and the m. levat. palp. sup. from which the m. levat. palp. sup. is separted by the intrusion of the connective tissue. In an embryo of $10 \mathrm{~mm}$. already all the muscles are developed as independent bundles, or they are spread flat-except for the division of the $\mathrm{m}$. rect. sup. and the $\mathrm{m}$. levat. palp. sup. At this stage the attachment of the musculature to the ocular wall is already distinctly defined, the various muscles are fixed on the connective tissue surrounding the eye, i.e., on the developing sclera. Yet at none of these stages is it possible to speak of any definite development and deposition of musculature, and the final arrangement of the musculature can be observed only after the embryo has exceeded $2 \mathrm{~cm}$. in length, and the facial region of the head has developed. For this the initial form and size of the developing eye are responsible. As I have stated in my earlier writings, in vertebrates the form of the eye undergoes very striking changes during development. The developing eye, at first decidedly oval with its longer axis dorso-ventral, grows into an oval form having its longer axis rostro-caudal, and the deposition and growth of the musculature corresponds with the successive phases of the developing eye.

In the Sus (the larger stages of which have been already dealt with by Kheil, Reuter, and Keibel) I have found the conditions, prevailing at the first developmental stage of the bulbar muscles, to coincide with those which I describe in the Spermophilus. I have not detected the slightest deviation either as regards locality of deposition or further development, even after the examination of a complete series of developmental stages. Moreover, I must add that no deviations can be detected even if I compare the developmental phase of the form of the eye to that of the muscles. The same must be stated in respect of the embryos which I could study only in incomplete series of several developmental stages (which again were studied only for the sake of comparison) of the Vespertilio, Cunicuius, and Canis, and also on a considerable number of the embryos of the Mus and Cavia. It may be stated that the development of muscles in higher mammals is governed by a common principle as regards the locality, deposition, and further growth.

The object of this study was to establish the very first beginning of the development of the orbital muscles in mammals. Further development and final arrangement of the musculature, as well as the first appearance of the fibrils of striated muscles, constitutes another department. 


\section{Summary}

1. In mammals we find no structures whatever that would correspond to the head cavities in lower vertebrates.

2. The first beginnings for the development of the muscles which move the eye-ball appear as a condensation of mesoblastic cells between the carotid artery and jugular vein. The condensation is located in the region of the process for the upper jaw, medial to the ganglion trigemini, in the spot where the chorda dorsalis at the cephalic pole of the embryo terminates.

3. On the caudal side the abducens, and on the rostral side the oculomotorius, grow towards this condensation.

4. The condensation appears first as a cylindrical body medial to the optic vesicle, the anterior portion of the condensation being entered by the trochlearis.

5. Then this cylindrical body grows to form digitiform processes, and thus the primarily cylindrical cellular body divides into separate muscles, namely : the $\mathrm{m}$. rect. ext., $\mathrm{m}$. rect. sup., and m. obl. sup. Later on, during the growth of this cellular condensation, part of the cells separates from the cellular group innervated by the $n$. oculomotorius, but nevertheless remains common for the $m$. rect. inf. and $m$. obl. inferior. On the other side the process for the $\mathrm{m}$. rect. int. separates from this cellular body.

The $\mathrm{m}$. rectus super. and $\mathrm{m}$. levat. palp. separate the last.

\section{BIBLIOGRAPHY}

1. Corning, H. K.- "Ueber die Entwickelung der Kopf und Extremitätenmuskulatur bei Reptilien." Morphol. Jahrbuch, Bd. 38, 1900.

2. Janošik, J.- "Anatomie človeka." 1923.

3. Kheil, R.-" Beiträge zur Entwickelungsgeschichte des Auges beim Schwein mit besonderer Berücksichtigung des Verhaltens der foetalen Augenspalte." Anat. Hefte Merckel u. Bonnet, Bd. 32, Jahrg. 1907.

4. Lešer, O.-I. "O vy̌voji okohybného svalstva u člověka." Rozpravy České Akademie, 1911.

II. " Ueber die Entwickelung der Form des menschlichen Auges.". Bull.intern. de l'Académie des sciences de Bohême, 1911.

III. "Ueber die Entwickelung des Auges bei einigen Vertebraten." Bull. intern. de l'Académie des sciences de Bohême, 1914.

5. Matys, V.- " Lývin a topografie svalstva v orbitě u ptáků." Rozpravy České Akademie, 1907.

6. Rex, H.-I. "Ueber das Mesoderm des Vörderkopfes dèr Lachmöwe." Morphol. Jahrbuch, Bd. 33, Jahrg. 1905.

II. " Zur Entwickelung der Augenmuskulatur der Ente." Morphol. Jahrbuch, Bd. 39, Jahrg. 1901. 